\title{
Narratives Shaping Teachers' Professional Identity and Influencing Career Development
}

Ariella Zeevi, Carmen Mihaela Crețu 


\title{
Narratives Shaping Teachers' Professional Identity and Influencing Career Development
}

\author{
Ariella Zeevi ${ }^{a^{*}}$, Carmen Mihaela Crețu ${ }^{b}$ \\ ${ }^{a}$ Achva Academic College, Hana Robina 1, Tel Aviv 6937201, Israel \\ ${ }^{b}$ Doctoral School of Faculty of Psychology and Education Science, "Alexandru Ioan Cuza" University of Iaşi, Toma Cozma Street 3, 700704, Iaşi, \\ Romania \\ *Corresponding author: ariellazeevi@ariella-z.co.il
}

\section{Abstract}

Keywords: narrative, professional development, professional identity
This article seeks to distinguish between teachers' academic studies which they chose of their own volition, and professional training throughout their career that is imposed on them as part of their role as educators, in the framework of their professional development. This is a qualitative-narrative study, whose data were collected through the life stories of two educators, one is currently serving as the principal of a junior high school, and the other serves as a vice principal of a junior high school and is also preparing to be the principal of a school. The data were analyzed by means of content analysis, which yielded themes that were combined into three chapters: Chapter one: The seeds sown in the parents' home towards professional life, Chapter two: The choice of the professional life track, and Chapter three: Professional development towards career advancement.

The findings show that this distinction points to the formation of teachers' professional identity: The free choice in academic study tracks contributes greatly to the formation of their professional identity, while continuing their training as teachers in the afternoon after a long school day, does not contribute to the formation of their professional identity. Some see these studies as an inconvenience and its main value for them is financial. The findings of this study reprise the question of the connection between teachers' training throughout their careers as formulating the perception of their professional identity.
Zusammenfasung

\section{Schlüsselworte:}

Erzählung, berufliche Entwicklung,

berufliche Identität
In diesem Artikel wird versucht, zwischen akademischen Studiengängen von Lehrern, die sie freiwillig gewählt haben, und einer beruflichen Ausbildung zu unterscheiden, die ihnen im Rahmen ihrer beruflichen Entwicklung im Rahmen ihrer Rolle als Erzieher auferlegt wird. Hierbei handelt es sich um eine qualitativ-narrative Studie, deren Daten aus den Lebensgeschichten zweier Pädagogen zusammengetragen wurden. Einer ist derzeit Schulleiter einer Realschule, der andere ist stellvertretender Schulleiter einer Realschule und bereitet diese ebenfalls vor Schulleiter sein. Die Daten wurden mittels einer Inhaltsanalyse analysiert, die Themen ergab, die in drei Kapiteln zusammengefasst wurden: Kapitel eins: Die Samen, die im Elternhaus für das Berufsleben ausgesät wurden, Kapitel zwei: Die Wahl des Berufslebens und Kapitel drei: Berufliche Weiterentwicklung zum beruflichen Aufstieg.

Die Ergebnisse zeigen, dass diese Unterscheidung auf die Herausbildung der beruflichen Identität der Lehrkräfte hindeutet: Die freie Wahl in akademischen Studiengängen trägt in hohem Maße zur Herausbildung ihrer beruflichen Identität bei, während ihre Ausbildung als Lehrkräfte am Nachmittag nach einem langen Schultag nicht fortgesetzt wird zur Bildung ihrer beruflichen Identität beitragen. Einige sehen diese Studien als Unannehmlichkeit und ihr Hauptwert für sie ist finanziell. Die Ergebnisse dieser Studie wiederholen die Frage nach dem Zusammenhang zwischen der Ausbildung von Lehrkräften während ihrer gesamten Laufbahn und der Formulierung der Wahrnehmung ihrer beruflichen Identität.

\section{Introduction}

The purpose of this article is to examine the narrative of the formation of professional identity of teachers as a result of learning in professional development throughout their careers.

The method: semi-structured interviews with two teachers, one who later became a school principal and another who serves as a pedagogic vice principal in a junior high school and undergoes a training process as a school principal. In addition, five stories of school vice principals were analyzed in view of the professional development process they underwent throughout their careers, while looking at its influence on the formation of their professional identity.

The research question: Do professional development processes affect the perception of teachers' professional 
identity, and to what extent do these affect the continuation of career development?

Contribution to knowledge: Some studies argue that the narrative contributes to the perception of professional identity (McAdams, 1993). This article seeks to build on this assumption and to examine how the concept of professional identity crystallizes in the learning of teachers during their professional development and how these affect the continuation of their career development.

Three decades ago, a "narrative shift" occurred in the social sciences which led to the use of the narrative as a tool for studying human reality. The perception that stories - narratives - are a major cognitive scheme (Bruner, 1987), central channels for imparting meanings (Polkinghorne, 1988), a significant means of shaping identity (McAdams, 1993), and a basis for interaction (Gergen \& Gergen, 1983), led to narrative research permeated into diverse social disciplines, including psychology, anthropology, sociology, history, social linguistics, communication, gerontology, gender studies, as well as the major social professions, including education, social work, psychotherapy, counseling and mediation.

Some distinguish between "narrative" and "story," but most social scientists use both terms interchangeably (Riessman, 2008). This study will use the term "narrative" and "story" as one and the same.

It is possible to discern a continuum, at one end of which is the narrow definition of social linguistics, according to which a narrative is a distinct discourse unit focused on a subject and organized over a time axis, and at the other end definitions used in social history and anthropology, which view the narrative as a complete life story, formed from pieces of interviews, observations, and documents. In the middle of the continuum are the prevailing definitions in psychology and sociology, that view narratives as lengthy reports of life within a context, which develop during a single interview or over several interviews (Riessman, 2008) in an attempt to integrate the key elements identified with the narrative form. Smith and Sparkes define a narrative as "a complex genre that often includes a point and characters alongside a plot that links events that are unfolded over time and space to provide an explanation or general outcome." (Smith \& Sparkes, 2009: 2).
Bruner $(1985,1996)$ argues that one can see two basic ways of knowing and thinking through which people organize and manage their worldviews: the positivist (paradigmatic, or logical-scientific) way, and the narrative way. The positivist path is based on the search for a universal position of truth and is suitable mainly for exact sciences. The narrative-constructivist way, through which one can know and grasp the world, is based on the assumption that the complex and rich phenomena of experience and of life are better represented in stories and narratives (Lieblich, Tuval-Mashiach, \& Zilber, 1998). The narrative approach is more suited to understanding the world of people and grasping their experiences.

People become narrative autobiographers in the way they tell about their lives (Riessman, 1993). People are natural storytellers, it is a quality of their human nature rather than an expression of artistic abilities (Lieblich, Tuval-Mashiach, \& Zilber, 1998; Beattie, 1995). The story is the landscape in which we live as human beings and function as people who find meaning (Elbaz-Luwisch, 1991).

The basic assumption underlying the claim to use narrative in sociology, psychology, and education studies is the perception of the human self as a narrator of stories and as constructing narratives about themselves and their environment (Bruner, 1990). Indeed, in recent decades, researchers have been using the methodologies of researching the self, the collaborative and narrative to understand educational phenomena, among other things through the help of people's stories about themselves (Culler, 1981; Iser, 1976) The story, therefore, is a fundamental way of the individual to give meaning to their experience, to bridge and reconcile the inner world of their thoughts and feelings, with the external world of observing actions and expressions of interest (Garro \& Mattingly, 2000).

Chase (2005) argued that a narrative can be delivered orally or in writing, and may be created during a field research, an interview, or a spontaneous conversation between people; in each case it may be a short and focused story about a specific event, or an extended story about a continuing aspect in the life of the narrator, or about a whole life course of the person from birth to the present. Chase proposes six common "lenses" for narrative researchers, through which the contribution of narrative writing can be characterized: (1) the story as creating meaning, (2) the story as expressing a voice, (3) the story 
as expressing and forming identity, (4) the story as representing change and development, (5) the story as a connection between the narrator and the listener, and (6) the story as a contextual product (Chase, 2005).

This article refers to the third lens: the story as expressing and forming identity. Two teachers were invited to write the story of their professional development and were asked in a semi-structured interview how much professional development contributed to their perception of their professional identity and to what extent these contributed to their career development. This raises the question: what is identity and what is the professional identity of teachers?

\section{Theoretical foundation}

The term "identity" can be defined by the question "who is or what is the person?" The different answers that persons give about themselves, or the meanings attributed to them by others, are those that define their identity (Beijaard, 1995). The early literature, such as Erikson (1968), describes the concept of identity in terms of the 'self.' According to Erikson, identity is a concept that changes and develops with age, which does not relate to what a person has, but to what they develop during their lifetime. Erikson defines the "identity of the self" as an inner sense of the individual - of their knowledge of themselves, of their path and of their goals in the future. This basic sense consists of a core personality (of attributes, wishes, desires, talents) that does not change. This core upholds the experiential sequence of the individual beyond situations and times. According to Erikson, identity is not a collection of the individuals' beliefs about themselves, it is more than the sum of these beliefs: it is an integrative organized perception, i.e. identity is not a 'description of myself' but an attempt to explain oneself, a task that requires complex integration.

The research views identity creation as an ongoing process, that includes repeated interpretation of experiences encountered by the individual (Kerby, 1991). Identity formation involves the process of creating identity, expanding it, and making changes within it through actions of self-evaluation (Cooper \& Olson, 1996). Self-evaluation and identity are part of a person's self-image and may therefore be threatened by changes that may affect their self-image and, consequently, their personal identity (Kozminsky \& Kluer, 2011).
Identity, then, is not imprinted in a person from the moment of birth, but rather a dynamic process of creation and construction in an ongoing process of interaction between the individual and the environment on one hand and the inner feelings of the person on the other. The construction of identity is a process by which a person strives to combine the roles and experiences in society into a coherent image of the self. Thus, teachers shape their professional identity through their interactions with themselves and with others (students, colleagues, parents, etc.) (Kozminsky \& Kluer, 2011). Part of a person's selfidentity is also their professional identity, which answers the question "Who or what am I as a professional?" There is a mutual influence between the professional identity and personal identity. Each identity influences and is influenced by the other, and therefore a change in each of them has an effect on the other (Kozminsky \& Kluer, 2011)

Professional identity is defined as the teachers' sense of belonging to the teaching profession and their identification with it (Tickle, 1999; Kremer \& Hoffman, 1981). Coldron and Smith (1999) expand this definition and explain that professional identity is the way the teachers are perceived not only by themselves but also by others. As a result, "self-perception" and "perception of others" are two elements whose interactions affect the professional identity and are affected by it (Reynolds, 1996).

The construction of the professional identity of a teacher is critical because the teachers bring themselves, their personality and professional identity in the classroom, in the discourse with the students, and in their teaching processes. Therefore, one must take into account that conflicts that arise within one's professional identity may undermine the teacher's sense of coherence as regards one's personal identity. Day, Elliot \& Kington (2005) argue that a change in educational policies and reforms, that usually occur as an expression of policy from above rather than a need from the field, create an ongoing identity crisis. They found that a crisis damages their commitment to teaching, the degree of motivation, sense of self-efficacy, satisfaction and professional pride, and their own internal coherence in relation to their professional identity. Therefore, Rodgers \& Scott (2008) call for teachers to strengthen their awareness of their professional identity and the contexts, relationships, and emotions that shape their identities. The call is for a change in the perception of teachers regarding themselves 
as professionals who shape their own identity. They are the ones who will express their professional voice rather than letting external forces do it for them.

The perception of teachers' professional identity has an impact on aspects of the teacher's personal and social environment:

1. Sense of self-efficacy, judgment, and the professional decisions - the perception of professional identity influences the sense of selfefficacy, judgment, and the professional decisions (Beijaard, Meijer, \& Verloop, 2004). Beijaard, Meijer, and Verloop (2004) argued that "Teacher identity - the beliefs that teachers have about teaching and learning as a teacher - is an essential issue in teacher training; it is the basis for creating meaning and making decisions...teacher training must therefore begin with the self-inquiry of the teacher" (p. 21).

2. Self-examination - professional identity is part of the role perception. Altman and Katz (2001) note that the role perception, i.e. the concrete way in which the professional perceives their professional identity and performs their role, is expressed in everything the professional uses to fulfill their duties: behaviors, work methods, mindsets, beliefs, declarations, etc. In their opinion, familiarity with the components of the personal role perception, their examination and raising them to awareness can help the teacher to examine the effectiveness of their perceptions and the behaviors derived from them and to improve them.

3. Professional development and attitude to changes - professional identity also determines to a large extent how teachers continue to learn and develop professionally, and what will be the attitude of teachers to educational changes and reforms (Knowles, 1992). If the teachers see themselves as professionals who keep up to date in the various aspects of their field of study and examine the new information in light of their work, it is likely that they will show interest and openness to professional development.

4. The status of the teacher - the perception of oneself is also influenced by teachers' socioeconomic status and prestige that society attributes to the group to which the person belongs (Schwarzwald, 1978). Teachers can strengthen their professional status and their self-image as professionals by taking the authority to form their professional identity (Rodgers \& Scott, 2008).

This article refers to the aspect of professional development and the attitude toward change, since professional identity determines to a large extent how teachers continue to learn and develop professionally and where they aspire to progress and develop as educators. The question arises, therefore, what is the professional development of teachers?

In this article, two forms of professional development are expressed: academic studies towards a degree in universities or colleges, and professional development that every teacher is required to undergo - these are referred to as "advanced courses". The critical difference between the two is that teachers' academic studies were performed by their own choice, while professional development studies are imposed upon the teacher, with limited ability of the teacher to choose what to learn. The choice is a motivator while coercion creates resistance.

The research question: "Do professional development processes affect the perception of teachers' professional identity, and to what extent do these affect the continuation of career development?" refers to the training that every teacher must complete throughout their career, as part of their obligations.

Professional development of teachers is perceived as adult learning, or "Andragogy." Alexander Kapp first coined the term in 1833. Malcolm Knowles popularized this term and therefore is associated with it. Andragogy is "the art and science of helping adults learn." It was developed in Europe and North America as a distinct theory to solve the problems in pedagogy, which is "the art and science of teaching children" (Hanson, 1996).

Knowles (1973:43) discusses four Basic Assumptions for Andragogy:

1. The first assumption is that when a person grows older, he/she become transformed from a dependent entity into a self-directed entity. The adults do not see themselves as learners who are dependent on the teacher, but as someone who is active through self-intention or as a creator. 
2. The second assumption is that the adult differs from the child in the way they perceive life experience. Children refer to experience as an external event that happened to them, while adults perceive it as part of their identity - "An adult is what they did with their lives."

3. The third assumption is that there is a difference between children and adults in readiness to learn. A developmental task is a task that arises at some point in a person's life and creates a readiness to learn, a moment in which one can be taught. Success in this task leads to success in future tasks.

4. The fourth assumption holds that children and adults differ in their orientation to learning. Children have a perspective of postponed application of knowledge: "What I learn in elementary school will help me in my high school studies." In contrast, adults relate to their studies from a perspective of immediacy of application: they want to immediately implement what they learn and see in their studies as a means to improve their ability to cope with life problems.

Since we seek to view the professional development of teachers as andragogy, we must examine how well teachers' professional development processes consider these basic assumptions.

Vidislavski (2011) argues that professional development is the constant development of professional knowledge and skills throughout the professional life-long learning of teaching staff. As an integral part of their work, teaching staff expand their knowledge, deepen their insights about teaching-learning processes, develop new teaching methods, and develop skills to promote students' functioning and achievements. The development takes place in the course of professional functioning, and learning takes place in diverse frameworks of teaching staff, within the roles and between the roles, in the fields of knowledge, in the fields of pedagogic management, and in the educational and organizational spheres. The professional development takes into account the educational continuum along the course of the development of students according to the corresponding age groups.

Professional development contributes to the improvement of professional identity, to the enhancement of the professional functioning of the teaching staff as an educator, teacher, and position holder (Vidislavski, 2011). Therefore, the professional development process is structured, systematic, and enables the development of accountability and commitment to the role.

The creation of a continuum of career development between training before the role and the professional development within the role will bring the teaching staff to a high level of expertise, and increase the prestige and status of teaching as a profession. Therefore, this study illustrates the process that teachers undergo from narrative writing towards reflection and from the formation of professional identity towards the continuation of career development.

\subsection{The narrative as human expression and identity formation}

When people tell their life stories, they become autobiographers (Riessman, 1993). Stories are part of our identity, we create stories about ourselves that we convey in a variety of ways to others. The creation of the selfnarrative enables us to understand who we are and where we seek to advance in our lives. (Gudmundsdottir, 1991) The research question, therefore, seeks to find an answer from the narrative approach that helps the storyteller to form his/her identity.

\section{Research methodology}

\section{Study design}

Four educators are at the center of this study. P1 is currently the principal of a junior high school in the south of Israel, P2 is a pedagogic vice principal of a junior high school in central Israel, P3 is a Middle school pedagogical coordinator and $\mathrm{P} 4$ is a homeroom teacher. In-depth interviews were conducted with P1, P3 and P4 and the vice-principal, while $\mathrm{P} 2$ wrote her professional life story from her childhood up to the present time when she attends a training course for future school principals. The choice of in-depth interviews stemmed from the desire to let the participants tell their stories about the subject of this study in their own language (Sparadley, 1979). For example,

P1: "The questions in the interview sharpened some things about myself, for example: the very fact that as a principal I perceive the courses differently than when I 
was a teacher. I understood that what I see as a principal is different from what I saw as a teacher..."

The principle is that every interview is a product of interaction between the speaker and the listener. In such conversations, both the listener and the speaker develop the meaning together, creating a story that is meaningful to both partners (Gudmundsdottir, 1996). The in-depth interview is a process of building a reality that both sides contributed to (Woods, 1996, p. 53). P2, the vice principal, has written her life story. "People are natural storytellers" (Lieblich, Tuval-Mashiach, \& Zilber, 1998, p. 7). They construct narratives about their lives and tell their life stories (Bruner, 1990). Telling stories about the past, present, and future events is considered as universal human activity and one of the first forms of discourse we learn as children (Riessman, 1993). The task of the interviewer, the author of this study is to help the interviewee construct his/her story.

\section{The research tool}

The study used semi-structured in-depth interviews. An in-depth interview is a qualitative methodological tool that combines flexibility and openness on the basis of built-in questions (Kouritzin, Piquemal, \& Norman, 2009; Fisherman \& Weiss, 2011; Hammack, 2008; McAdams, 1990). During the interview, the interviewees were asked to describe their life story, starting from their parents' home, through their continuing professional development and up to the time of the interview. The interviewees were invited to address their professional identity in general, and especially with regard to the formation of their professional identity in their learning process and professional development over the years. In the course of the interviews, clarifying questions or questions directed at the subject of the study were sometimes asked, especially regarding professional development courses.

\section{Analysis of life stories}

Two main types of analyses are common in narrative research: analysis of narratives and narrative analysis (Elbaz-Luwisch, 1997; Polkinghorne, 1995). The analysis of narratives approach uses the collection of stories of a group with a common practice, and analyzes them to reach a generalization about a group or a phenomenon under study (Bruner, 1986). Narrative analysis is a research that is done with narrative, in which personal or shared singular cases are examined. Its goal is to produce a narrative creation that will provide the data with full and profound meaning, and the data collected from the stories aggregate into common themes. This study uses narrative analysis to create a narrative that can answer the research question: Do professional development processes affect the perception of teachers' professional identity, and to what extent do these affect the continuation of career development?

The narrative analysis in this study was carried out according to the stages depicted in figure 1 (Kassan \& Krummer-Nevo, 2010).

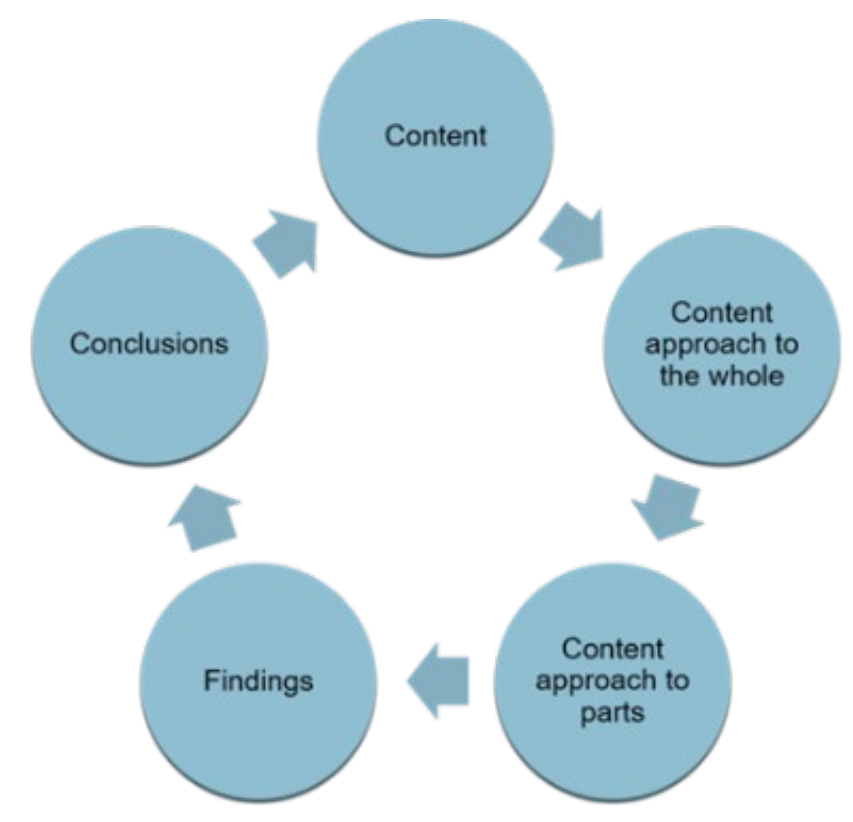

Figure 1. The stages of narrative analysis

\section{Results}

\subsection{The three chapters of life stories}

The life stories were organized around three chapters: The seeds sown in the parents' home towards professional life, the choice of the professional life track, and professional development towards career advancement.

Chapter one: The seeds sown in the parents' home towards professional life

This chapter incorporates stories from childhood, from accepting values from the parents' home, and the formation of a professional, value-based worldview.

P1: "Ever since I was a little girl, I wanted to be a teacher. I really love this field. I think it's amazing."

P2: "To this day my connection with my father is the strongest, and I have no doubt in retrospect that my father 
is a very significant figure for me, in the person I grew up to be, and in the personal and professional identity that I formulated."

P3: "Many of my family members are educators in various areas of education. I wonder how much this fact affected the continuation of my professional development. I experienced and absorbed an 'educational spirit'. I believe that this 'educational spirit', the values into which I grew up in such a family, are like seeds sown for my continued professional development, namely choosing a profession that encompasses a human touch, requires attention, support and giving to others, acceptance, empathy, and so on..."

P4: "As the third sibling, my two older brothers were a role model for me. I chose in fact to study in an orthodox high school (unlike my three brothers). However, the efforts, learning from failure, and determination were their strong point and they embedded them in me..."

\section{Chapter Two: The choice of the professional life track}

This chapter incorporates the "self" perception of the current professional identity, coping with challenges with respect to the perception of personal self-efficacy, and the place of professional development courses.

The choice of the teaching profession:

P1: "I went to study, got my bachelor's degree and went back to teaching. In a high school as a homeroom teacher and in the second year as an English teacher, from 1994 to 2016 - 22 years. I taught junior high school and high school. I have had a lot of roles: subject-matter coordinator, grade level coordinator, schedule coordinator, evaluation coordinator... all these years $I$ always had a role, I submitted to matriculation exams, and I evaluated matriculation exams. Two years ago, I won a tender for school principal after many attempts. Now I have been managing a junior high school for two years now..."

P2: "I knew that I came with the tools and skills that I acquired during the four years of teacher training and practical work, and I decided in my heart that I would not let the fears affect me and that I would do the best I could to succeed and advance..."

P3: "I studied special education plus sociology and anthropology towards a B.A. degree. Later on, I attended courses for a teaching certificate in special education. Throughout all my years of studies, I continued working in the kibbutz educational frameworks. It offered me extensive field experience and expanded my learning beyond theories. I graduated with distinction and it contributed to me..."

P4: "My parents had no formal schooling but they insisted that we, the children, would learn and learn and learn... For me, my father, a 'teacher' figure, was the peak of selfrealization. I think that he embedded it in me... And indeed, when I became a teacher, it was his greatest pride, I felt that I had closed a circle..."

The place of advanced courses in achieving professional development:

P1: "The school advanced courses did not contribute anything to me, they were boring and irrelevant, except for a small number of them that gave my teaching tools, that helped. What contributed most to me is my graduate studies at the university, I learned about motivation theory, what causes internal motivation, if I once believed that everyone should be kept on a 'short leash'...this learning changed my worldview from one end to the other. I have learned that support, tolerance, etc., are not difficult words."

P2: "Looking back, I can say with certainty that what gave me confidence is the period of college studies. I thought that if I managed to meet all the goals I set for myself at this time, I had the ability to cope with what was required of me as a grade level manager."

"In addition, my studies revealed to me a whole world of management principles and I felt that I was ready for it on a professional and mental level."

P3: "The in-service training courses are usually given at the end of the work day, after an arduous day in class, and exhaustion prevails! Unfortunately, except for one inservice training course that gave me practical instruments, I remember none of them as meaningful, a course that will leave its mark and contribute to me in the school experience."

P4: "During these years, I have attended several inservice training courses about various topics, e.g. sciences, class management, individual hour teaching and differential teaching. These courses contributed a lot since they offered practices that I could implement in my 
teaching. On the other hand, there were quite a few inservice training courses that I was obliged to attend. They did not interest me and had no benefit for me. I would prefer being able to choose every year what to learn and in which direction to grow..."

Chapter Three: Professional development towards career advancement

This chapter refers to the aspirations to continue career development based on current achievements and on the basis of self-perception - the personal and professional identity.

P1: "From day one I knew I wanted to manage, it was always aimed there, I see myself as a six-year principal." (now a junior high school principal and aspiring to be a six-year principal, grades 7-12).

P2: "At that time, my perception of myself was shaped not only as a teacher but also as an educator, and the desire was awakened in me to place myself in a position where I could also influence profound processes in education."

Each of the chapters was divided into several categories that were extracted from the text and written in the personal narrative. These categories were repeated throughout the narrative.

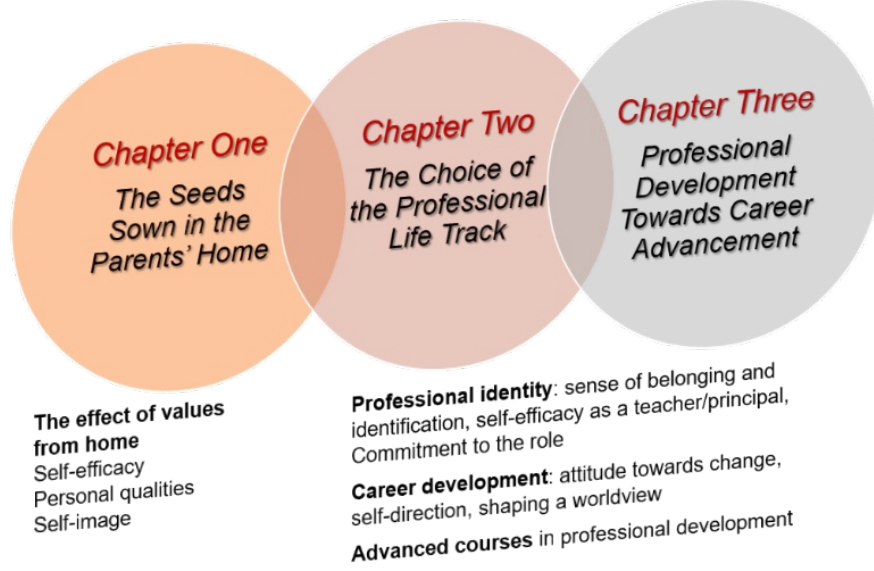

Figure 2. The three chapters of life stories and their categories

In chapter one, the values from the parents' home have had the most dominant influence, and from them emerged high self-efficacy and high self-image, and these shaped the personal qualities of the interviewees.

In chapters two and three, there is an emphasis on the influence of values from home, on a sense of high self- efficacy, on shaping the worldview as an educator, high commitment to the role, and a sense of belonging and identification with the teaching profession. The academic studies that take place in the second chapter seem to have had the greatest influence on the perception of professional identity and the sense of efficacy to continue career development, alongside inspirational figures and mentors, who strengthen the perception of professional identity.

\subsection{Identity, professional development, and the continuation of career development: do they go together?}

At the center of this article is the question: Do professional development processes affect the perception of teachers' professional identity, and to what extent do these affect the continuation of career development?

\section{Chapter one: The seeds sown in the parents' home}

P1: "The direction at home was that a woman should be a teacher...In Russia, being a teacher was very honorable... that was always the direction. Education was the most meaningful."

P2: "My father's education to his daughters was liberal, empowering, and encouraging excellence. I remember him always saying emphatically: 'You will study, get degrees, work in jobs that will enable you to be independent and not dependent of your husbands..."

P3: "Until today I feel that work is my first priority, like my father. The feedbacks that I receive, provide a lot of meaning, I know that I am in the place that is right for me..."

P4: "Both in my adulthood and my professional choices, the home where I grew, the education and general atmosphere there, affected me and served as a lighthouse for me..."

P1, who was born in Russia, immigrated to Israel when she was 4 years old. At home she received a conservative education aimed at excellence and practical choice of a profession that would enable her to make a decent living:

P2:"I knew that there would always be a living in teaching English and that I could give private lessons and earn more money, and that's indeed what happened." 
P2, was born in a development town in the south of Israel (a development town is a place for new immigrants from Asia and Africa). She has five sisters and a brother. The economic situation at home was not good. And at the same time, P2's father was a public activist and brought P2 in particular close to him, gave her the feeling that she was the most successful and outstanding of all the children:

P2: "I remember dad calling me, sitting me on his lap and I felt the most special in the world, special that I am the only girl who has the right to be a partner in such adult conversations."

P1 became a teacher because of the message she received at her parents' home and she studied architecture but retrained in teaching as a professional. She chose teaching because she was searching for a role with meaning derived from the education she received at home. Both P2 and P1 emphasize their personal qualities as supporting and driving their professional development.

P1: "I always wanted to manage and I knew I would be a principal, I enjoy it very much..."

P2: "I realized that school position holders notice me when I initiate, invest, make an effort...I have emerged as a pioneer in a significant way..."

The first chapter, the parents' home, sows the seeds that will eventually become career paths and professional development:

P2: "Of all my sisters and even my only brother, my father's connection to me was the strongest and the closest. Even though it was never said aloud, everyone knew that I was 'daddy's successful, smart, and beautiful girl'. "

P1: "At home I was directed to look for a practical profession. I knew that there would always be a living in teaching English and that I could give private lessons and earn more money, and that's indeed what happened."

In summary, each of the educators interviewed for this study had a different life story. They came from a completely different social and cultural family background. And despite the great diversity, what the two share is that the home, the parents, and the cultural environment influenced the values and motivation for further personal and professional development. The parents' home greatly influenced the shaping of the identity of the adult. It is possible to examine how the formation of identity perception is an evolving process and is influenced by the family environment. Identity is not a constant attribution of the individual, but rather an evolving and changing characterization. The development of self-identity takes place as an ongoing process between the individual and their environment. In this process each person interprets oneself, what kind of person one is, and how he/she is identified in a given context. That is, selfidentity is the perception of oneself in a particular context. In this sense, the finding strengthens the words of Beijaard, Meijer, and Verloop (2004).

\section{Chapter two: The choice of the professional life track}

P1 and P2, each on her own path turned to academic studies; P1 studied English and teacher training, and P2 first studied architecture and then converted to education and science. Each of them pointed out that the foundation for shaping their professional identity was laid during their academic studies and later in their choice to undergo training towards school principalship.

P2: "I knew that I came with the tools and skills that I acquired during the four years of teacher training and practical work."

"Looking back, I can say with certainty that what gave me confidence is the period of college studies."

P1: "What contributed most to me is my graduate studies at the university, I learned about motivation theory, what causes internal motivation, if I once believed that everyone should be kept on a 'short leash'...this learning changed my worldview from one end to the other. I have learned that support, tolerance, etc., are not difficult words."

In other words, the choice of professional life led the two participants in the study to academic studies in order to enable the choice and in accordance to it. The choice of the education and the teaching track was their free choice and in accordance with the values that each received in the parents' home, which also includes the ability to influence, to 'go far'.

\section{Advanced courses and teacher professional development}

Every teacher in the Israeli education system is committed to continuing their professional development, to learning and continuing education. The basic assumption is that 
continued learning enriches, develops, and strengthens the perception of professional identity. At the same time, each of the educators who told their stories does not consider the studies that were imposed on them as a significant contribution, apart from a few seminars, especially those that contributed to their toolbox as teachers and thus their sense of self-efficacy in teaching.

P2: "I participated in various courses in the fields of differential teaching, youth psychology, the unique schedule of the 'Ofek Hadash' reform, and more, but there was one advanced course that was meaningful for me to develop my professional identity - the course for the twoyear grade level coordinators."

P1: "I took a successful English advanced course that was related to meaningful learning, a useful course from which I learned a lot..."

P1: "I made a mistake, at first I did not study in advanced courses and I was not encouraged to do so, not only from the financial point of view, no one cared...once I realized that it had financial significance, I started to do it. At that time, I was also doing my master's, then I started doing a lot of advanced courses, first because of the financial aspect and then because of the reform..."

"And apart from those individual courses that strengthened my sense of self-efficacy by providing practical tools, after all, professional development is perceived as a burden, irrelevant and not advancing, but eventually necessary for financial advancement"

In other words, the advanced courses as a framework for professional development were seen as an option for the financial advancement of the two teachers.

\section{Attitude towards change}

P2 points to every change in her professional life as increasing motivation, satisfaction, and her sense of meaning in the work of education:

\section{P2: "In August of that year, after I had already finished} preparing for receiving a new grade as principal, I was approached by the junior high school principal and the six-year principal, who offered me the position of vice principal, and I was very surprised by this proposal. There were five other worthy grade-level coordinators and I was the youngest of them professionally, yet they chose me...me! They saw me as the most suitable for the job. There are not enough words to describe the level of the satisfaction, the joy and the tremendous motivation that arised in me because of this. This time only one minute was enough for me to say yes. At this stage I already knew my ambitions, my abilities, and I understood my mission. I felt that this role played an important part in the formation of my professional path and that it will reveal to me the missing pieces in the puzzle toward realizing my goal."

With regard to advanced courses and professional development, P2 did succeed in taking part in some courses, but her academic studies were the ones that contributed to her professional identity and her sense of self-efficacy:

P2: "I participated in a number of professional advanced courses in the fields of biology and chemistry. These courses revealed interesting and innovative teaching methods, and I made sure to incorporate this new knowledge into lessons..."

"My studies revealed to me a whole world of management principles and I felt that I was ready for it on a professional and mental level."

"Looking back, I can say with certainty that what gave me confidence (to serve as a grade level coordinator) is the period of college studies."

P1 points to a positive and challenging attitude to any change that occurs when a new role is taken, and especially a management role:

P1: "I was very happy, and from every position I grew, I learned, I advanced both professionally and personally."

Along with the great motivation of each of the teachers for any change in their educational role, changes resulting from the requirement for professional development were greeted with less joy and motivation, mainly because they were forced from the top down. P1 attests that as a teacher, she was not interested in advanced courses that seemed irrelevant and boring to her, but as a principal, she began to understand their great value, mainly because she must lead the professional development of teachers, because her perspective has changed.

P1: "Also a worldview beyond professional development through advanced courses, I really believe in professional 
development; as a teacher I did not like the advanced courses, and now as a principal I see their value..."

"The only way to empower teachers is to give them a platform, whether through professional development or not. Since teachers have no options for progress, then if that can be given to them it will be a platform for progress. At this stage I am considering motivating teachers to engage in their own professional development at school, that is, any teacher who is willing, is welcome to give a training course to the entire teaching staff... this idea was welcomed by them."

\section{Formulating a worldview as an educator}

$\mathrm{P} 1$ received a strict education at home, indicating that at the beginning of her educational career, her worldview was very rigid. Her M.A. studies constituted a turning point for her in terms of her educational worldview, mainly in various theories of motivation and later on in her work alongside a school principal who was her role model and inspiration:

P1: "My perception at first was very rigid, setting clear boundaries. The aspects of tolerance, the understanding that not everyone was able to deal with situations that to me seemed simple, did not exist at all, and that caused resistance towards me. With time I learned to cut corners, to listen to the difficulty, to understand that not everything has to be accurate...the change was not easy because that's what I learned from my parents..."

P1: "In my M.A. studies I learned a lot about theories of motivation, and I connected a lot to a model of support for efficacy, belonging and autonomy, and I connected to it because I also experienced it with my father (a school principal himself), he really enabled exactly these aspects and since this experience was good and empowering for me, I realized that this is how we should work with others..."

P2 was educated in a home that challenged her towards management roles and aspirations. Her educational worldview was shaped through the accumulation of her experience at the school, and positive feedback she received from both the students and the school principal, who was a role model for her:
P2: "At the end of my first year as a grade level coordinator, the six-year principal, who was an admired and special person, a senior and experienced person, held a yearly summary meeting with me in which he praised my work and noted that he saw in me tremendous development at an extraordinary pace in this year. He told me that my development in one year was equivalent to several years with other grade level coordinators in the past. I think that this was the first time I really understood how senior managers perceive me, and as I write these words and think about this conversation in retrospect, I also understand that in this conversation, the knowledge that one day I would be a school principal was affirmed, like a seed that was underground, and as soon as it was watered it managed to sprout. I did not know how long it would take for this sprout to grow into a real flower or in what roles I would serve until then, but I knew it was my destiny."

In summary, P1 and P2, both chose their professional track in the education system as a free choice. Each of them knew when they chose this track that they were headed towards management. Each one of them attests to the fact that the choice was based in guidance from home, from the messages they received, and later on the reinforcement they received from their academic studies. None of them mentioned the professional development courses as intensifying their motivation to be a principal. The main reinforcement came from their studies for the bachelor's and master's degrees. Each saw herself as coping well with changes and as seeing change as a platform for something new, something that stimulated progress. The common denominator was therefore the choice of studies rather than the demand to take advanced courses that were imposed from above. The choice is authentic to the personal and professional identity, while the demand from top-down raises resistance.

Chapter Three: Professional development towards career advancement

P1 was interviewed for this research when she was already a junior high school principal in southern Israel. P1 describes herself as someone who has always known she would like to run a school:

P1: "From day one I knew I wanted to manage, it was always aimed there. In the future I would like to advance and manage a six-year school (grades 7-12)." 
As far as P1 is concerned, what will prepare her for this, and enhance her sense of efficacy are the experience that she accumulates and her work alongside the six-year principal whom she views as her mentor:

\section{P1: "I'm learning about myself and I'm growing, most of} my professional development is from my work as a principal and alongside the six-year principal, I feel very good about it. He has a very warm attitude towards me, and it fills an important void in me."

P2 wrote her professional life story after finishing her master's degree in educational systems management. According to her, it was these studies that instilled in her the great sense of efficacy towards management and directed her to continue professional development in the direction of running a school.

P2: "At the end of this period, I signed up for a master's degree in education systems management at Achva College, with the goal of taking on a management position in my school. I felt that I want and that I could fly as far as possible, like a butterfly."

At the end of her master's degree, she was accepted to a school principalship training course, and during this period she undergoes a training process that will culminate in the management of a six-year school (grades 7-12).

\section{P2: "I am finishing this chapter full of anticipation and} excitement for the next year to discover new chapters in my professional life, more avenues, and optimal selfrealization!"

P2 also notes that one of the decisive factors in shaping professional identity for further development was the school principal as an inspiration, and as a mentor who empowers the teacher:

P2: "At the end of my first year as a grade level coordinator, the six-year principal, who was an admired and special person, a senior and experienced person, held a yearly summary meeting with me in which he praised my work and noted that he saw in me tremendous development at an extraordinary pace in this year. He told me that my development in one year was equivalent to several years with other grade level coordinators in the past. I think that this was the first time I really understood how senior managers perceive me."
In summary, the third chapter which dealt with career development, emphasized the presence of a mentor, the principal of the school, as a person who lights the way forward, who encourages, praises and empowers. The power of a mentor lays in shaping professional identity and in influencing career development. What began in the first chapter in the parents' home as the father or mother figure who provided values and motivation, appears in the third chapter as a mentor - the one who continues the dominant figure from childhood.

\section{Discussion}

The life stories of the two educators point to an ongoing process of forming an identity from childhood, the parents' home, and later through higher academic studies. The study views identity creation as an ongoing process that includes interpretation and re-interpretation of the experiences of the individual (Kerby, 1991). Life stories suggest that there is a mutual influence between professional identity and self-identity. Each identity influences and is influenced by the other (Kozminsky \& Kluer, 2011). The identity formation of the two educators whose stories have been shared here is a process by which both P1 and P2 strove to combine their various roles over the years into a coherent image of the self (Kozminsky \& Kluer, 2011).

And at the same time, we can identify three anchors that shape professional identity: The parents' home, academic studies and an inspiring role model. The third anchor can be seen to some degree as a return to the parents' home, to the significant figure. The relationship between each of them with the school principal supports and enhances their perception of their professional identity. The process of identity formation takes place over time and through creating relationships with others (Cooper \& Olson, 1996). Coldron and Smith (1999) claim that the professional identity is the way in which the teacher is perceived as a teacher not only in their own eyes but also in the eyes of others, and indeed, P2 and P1 claim that when they received feedback from colleagues or position holders, they understood how they were perceived by others and it encouraged them to strengthen and form their professional identity. And indeed, the professional identity encapsulates two components that share a reciprocal relationship (Tickle, 1999).

There is no doubt that the identity of the two teachers is dynamic, from childhood to the present stage in which 
they are currently. Identity in general is dynamic and is in a constant process of formation and development. Identity is therefore not stable and may change according to the context and because it is multifaceted. This finding is supported by researchers who argue that the professional identity does not consist of one identity, but includes different sub-identities (Beijaard, Meijer \& Verloop, 2004). Both P1 and P2, who were already interviewed as school principals, raise throughout their life story their identity as a teacher and as a holder of other positions at the school.

\section{Free choice versus coercion from above}

In both stories it is possible to identify that when the teacher was given free choice for the path of academic studies for the purpose of professional development, the choice reflected taking responsibility for the outcomes, and a high level of internal motivation that affects the continuation of career development as well as the perception of professional identity. On the other hand, during the years of working as teachers, when they were forced into taking advanced courses as part of the professional development, it raised resistance, they did not succeed in benefiting from them except for a minority of courses that provided tools for implementing their work as teachers.

P2, on her choice of continuing the academic track:

"At the end of this period, I signed up for a master's degree in education systems management at Achva College, with the goal of taking on a management position in my school. I felt that I want and that I could fly as far as possible, like a butterfly."

P1, on her master's studies as shaping her educational worldview:

"For example, in my master's degree, I learned about motivation theory, what causes internal motivation, if I once believed that everyone should be kept on a 'short leash'...this learning changed my worldview from one end to the other. I have learned that support, tolerance, etc., are not difficult words."

The findings are summarized in the following model presented in figure 3 .

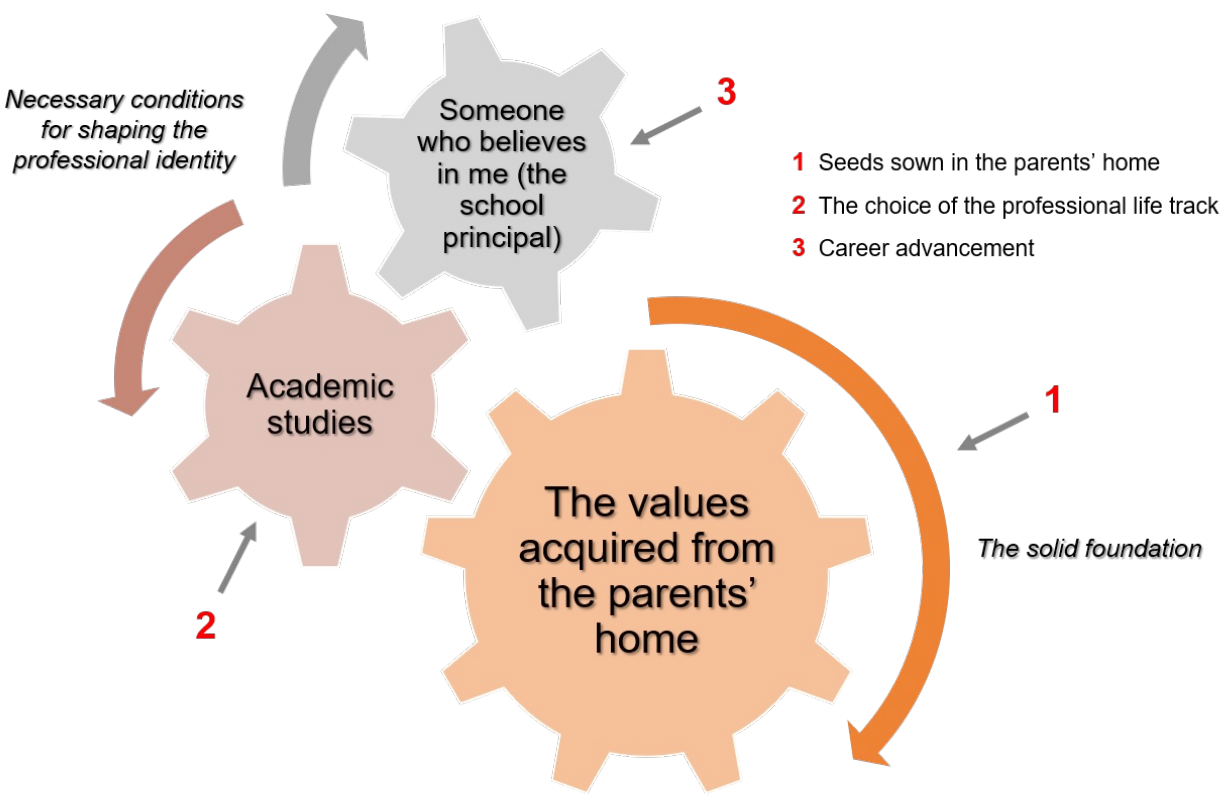

Figure 3. Professional identity, professional development, and career advancement

Figure 3 shows that:

1. The parents' home - provides values, inspirational characters, and creates the solid foundation of a sense of efficacy and perception of personal identity.
2. The choice of academic studies - as a free choice that is nurtured from the parents' home, enhances the perception of personal identity and hence the professional identity. 
3. Towards the continuation of career development at its center is an inspiring figure, a mentor, a school principal who enhances the sense of selfefficacy and professional identity.

The advanced courses that the teachers have undergone throughout their careers as educators and are part of the professional development have not been mentioned in their personal stories as shaping the perception of professional identity or as a driving force for further career development. There were advanced courses that contributed to them to a certain extent, but they did not help form a worldview, perception of professional identity, nor motivated the continuation of career development:

P1: "I took a successful English advanced course that was related to meaningful learning, a useful course from which I learned a lot and implemented, and I bring it with me as a principal."

\section{P2: "I participated in a number of professional advanced} courses in the fields of biology and chemistry. These courses revealed interesting and innovative teaching methods, and I made sure to incorporate this new knowledge into lessons..."

\section{Conclusions}

Teachers, educators, as well as other professionals, develop when they are in conditions conducive to learning and experiences of support and challenge. Kegan (1994) observed that "people grow best when they continuously experience an ingenious blend of support and challenge; the rest is commentary" (p. 42).

The writing of this article stems from a desire to understand the extent to which the teachers' professional development, the 'advanced courses', contribute to their perception of their professional identity and drives them to continue their career development. The basic assumptions of professional development of teachers relate to the fact that their professional development shapes and enhances the perception of professional identity.

From the stories of the two educators interviewed for this article, each of which is still in the process of career development with aspirations for continuing, it is evident that the main contributors to their perception of professional identity, as well as their sense of efficacy lie in each of the three chapters detailed in this article: the parents' home and the values they absorbed in it, the choice of academic studies for the career track of teaching, and a meaningful and inspirational figure the believes in them and drives them towards continuing their career development. The place of advanced courses in their professional lives is localized - in places where the course provides tools and skills and financial advancement, they contribute to improving teaching, but they do not shape the professional identity or motivate the continuation of career development.

It seems that each chapter can be seen as standing in its own right, but from a bird's eye view it seems that these chapters are intertwined and connected, when the parent figure (P1) or the father figure (P2) reappear in another variation in the third chapter as an inspiring and motivating figure.

\section{Authors note:}

This article was elaborated in the frame of the Ph.D. Doctoral School of the Alexandru Ioan Cuza University of Iasi (UAIC), Romania.

Ariella Zeevi is a PhD student at UAIC in Iasi. Ms. Zeevi is a psychotherapist and a teacher trainer. Her research area is teachers' professional development and growth. Ms. Zeevi has published articles about teachers' professional identity in the light of reforms in education. Ms. Zeevi also managed a high school of Art.

Crețu Carmen Mihaela is Professor, Ph.D., Psychology Education Sciences, Faculty of Psychology and Education Sciences, "Alexandru Ioan Cuza" University of Iaşi.

\section{References}

Altman, A., \& Katz, T. (2001). Leadership and leadership development: Theory and practice. (In Hebrew).

Beattie, M. (1995). Constructing professional knowledge in teaching: A narrative of change and development. New York: Teachers College Press.

Beijaard, D. (1995). Teachers' prior experiences and actual perceptions of professional identity. Teachers and Teaching, 1(2), 281-294.

Beijaard, D., Verloop, N., \& Vermunt, J. D. (2000). Teachers' perceptions of professional identity: An exploratory study from a personal knowledge perspective. Teaching and Teacher Education, 16(7), 749-764. 
Beijaard, D., Meijer, P.C., \& Verloop, N. (2004). Reconsidering research on teachers' professional identity. Teaching and Teacher Education, 20(2), 107-128.

Bruner, J. (1985). Narrative and paradigmatic mods of thought. In Eisner, E. (Ed.) Learning and teaching the ways of knowing (pp. 97-115). Chicago: NSSE.

Bruner, J. (1986). Actual minds, possible worlds. Cambridge: Harvard University Press.

Bruner, J. (1987). Life as narrative. Social Research, 11-32.

Bruner, J. (1990). Acts of meaning. Cambridge. Massachusetts: Harvard University Press.

Chase, S. E. (2005). Narrative inquiry: Multiple lenses, approaches, voices. In Denzin, N. K., \& Lincoln, Y. S. (Eds.), Handbook of qualitative research (3rd ed., pp. 651-679). Thousand Oaks, CA: Sage.

Coldron, J., \& Smith, R. (1999). Active location in teachers' construction of their professional identities. Journal of Curriculum Studies, 31(6), 711-726.

Cooper, K., \& Olson, M.R. (1996). The multiple Ts' of teacher identity. In Komf, M., Bond, W. R., Dworel, D., \& Boak, R. T. (Eds.), Changing research and practice: Teachers' professionalism, identities, and knowledge (pp. 78-89). London: Falmer Press.

Culler, J. (1981). The pursuit of signs: Semiotics, literature, deconstruction. Ithaca, NY: Cornell University Press.

Day, C., Elliot, B. \& Kington, A. (2005). Reform, standards and teacher identity: Challenges of sustaining commitment. Teaching and Teacher Education, 21(5), 563-567.

Edwards, R., Hanson, A., \& Raggatt, P. (Eds.) (1996). Boundaries of adult learning. London: Routledge.

Elbaz-Luwisch, F. (1991). Research on teacher's knowledge: The evolution of a discourse. Journal of Curriculum Studies, 23(1), 1-19.

Elbaz-Luwisch, F. (1997). Narrative research: Political issues and implications. Teaching and Teacher Education, 13(1), 7583.

Erikson, E.H. (1968). Identity: Youth and crisis. New York: Norton.

Fisherman, S., \& Weiss, I. (2011). Professional identity of teachers: The concept and its measurement. Dapim, 51, 39-56. Mofet Institute (in Hebrew).

Garro, L.C., \& Mattingly, C. (2000). Narrative as construct and construction. Narrative and the cultural construction of illness and healing (pp. 1-49). Berkley, CA University of California Press.

Gergen, K.J., \& Gergen, M.M. (1983). Narratives of the self. In Sarbin, T. R., \& Scheibe, K. E. (Eds.), Studies in social identity (pp. 254-273). New York: Praeger.

Gudmundsdottir, S. (1991). Story-maker, story-teller: narrative structures in curriculum. Journal of Curriculum Studies, 23(3), 207-218.

Gudmundsdottir, S. (1996). The teller, the tale, and the one being told: The narrative nature of the research interview. Curriculum Inquiry, 26(3), 293-306.

Hammack, P. L. (2008). Narrative and the cultural psychology of identity. Personality and Social Psychology Review, 12(3), 222-247.

Hanson, A. (1996) The search for separate theories of adult learning: does anyone really need andragogy? In R. Edwards, A. Hanson, \& P. Raggatt, (Eds.), Boundaries of adult learning. London: Routledge.
Iser, W. (1976). The act of reading: A theory of aesthetic response. Baltimore, Johns Hopkins University Press.

Kassan, L. \& Krummer-Nevo, M. (2010). Data analysis in qualitative research. Ben-Gurion University.

Kegan, R. (1994). In over our heads. Cambridge, MA: Harvard University Press.

Kerby, A.P. (1991). Narrative and the Self. Indiana University Press.

Knowles, M. (1973). The adult learner: A neglected species. Houston: Gulf Publishing Company.

Knowles, J.G. (1992). Models for understanding pre-service and beginning teachers' biographies: Illustrations from case studies. Studying Teachers' Lives, 99-152.

Kouritzin, S.G., Piquemal, N.A., \& Norman, R. (Eds.). (2009). Qualitative research: Challenging the orthodoxies in standard academic discourse(s). Routledge.

Kozminsky, L. (2008). Professional identity in teaching. Shviley Mechkar, 15, 13-17.

Kozminsky, L., \& Kluer, R. (2011). The construction of the professional identity of teachers and teacher educators in a changing reality. Dapim, 49. Mofet Institute (in Hebrew)

Kremer, L., \& Hoffman, Y. (1981). Professional identity and leaving the teaching profession. Iyunim beHinuch, 30, 99-108. (In Hebrew).

Lieblich, A., Tuval-Mashiach, R., \& Zilber, T. (1998). Narrative research. London: Saga Publications.

McAdams, D.P. (1990). Unity and purpose in human lives: The emergence of identity as a life story. In Studying persons and lives (pp. 148-200). Springer.

McAdams, D.P. (1993). The stories we live by: Personal myths and the making of the self. Guilford Press.

Polkinghorne, D.E. (1988). Narrative knowing and the human sciences. Suny Press.

Polkinghorne, D.E. (1995). Narrative configuration in qualitative analysis. International Journal of Qualitative Studies in Education, 8(1), 5-23.

Reynolds, C. (1996). Cultural scripts for teachers: Identities and their relation to workplace landscapes. In: M. Kompf, W. R. Bond, D. Dworet \& R. T. Boak (Eds.), Changing research and practice: Teachers' professionalism, identities and knowledge (pp. 69-77). London: Falmer Press.

Riessman, C.K. (1993). Narrative analysis. London: Sage Publications.

Riessman, C.K. (2008). Narrative methods for the human sciences. Thousand Oaks, CA: Sage.

Rodgers, C.R., \& Scott, K. (2008). The development of the personal self and professional identity in learning to teach. In M. Cochran-Smith, S. Feiman-Nemser, D.J. McIntyre, \& K.E. Demers (Eds.), Handbook of research on teacher education: Enduring questions in changing contexts (3rd ed.). New York: Routledge, Taylor \& Francis Group.

Schwarzwald, Y. (1978). A window to social psychology. Tel Aviv: The Open University. (In Hebrew).

Smith, B., \& Sparkes, A. (2009). Narrative inquiry in sport and exercise psychology: What can it mean, and why might we do it? Psychology of Sport and Exercise, 10, 1-11.

Sparadley. J.P. (1979). The Ethnographic Interview. New York: Holt, Rinehart and Winston.

Tickle, L. (1999). Teacher self-appraisal and appraisal of self. In Lipka, R.P., \& Brinthaupt, T.M. (Eds.), The role of self in 
teacher development (pp. 121-141). Albany, New York: SUNY Press.

Vidislavski, M. (2011). Reforms in the education system. Jerusalem: Ministry of Education. (In Hebrew).
Woods, P. (1996). Researching the art of teaching: Ethnography for educational use. London: Routledge. 